\title{
The Cross-Section of Stock Returns: An Application of Fama-French Approach to Nepal
}

\author{
Sabin Bikram Panta1, Niranjan Phuyal', Rajesh Sharma1, Gautam Vora ${ }^{2 *}$ \\ ${ }^{1}$ Department of Finance, School of Management, Kathmandu University, Lalitpur, Nepal \\ ${ }^{2}$ Department of FIT Management, Anderson School of Management, University of New Mexico, Albuquerque \\ Email: vora@unm.edu
}

Received 11 January 2016; accepted 23 February 2016; published 26 February 2016

Copyright (C) 2016 by authors and Scientific Research Publishing Inc.

This work is licensed under the Creative Commons Attribution International License (CC BY). http://creativecommons.org/licenses/by/4.0/

(c) (i) Open Access

\begin{abstract}
We study a sample of the companies listed on the Nepal Stock Exchange (NEPSE) for the predictors of the returns on these companies' stocks. Using the sample period of December 2004 through July 2011, we study the sample of 134 companies out of a universe of 176 companies. We construct the marketwide indicators of Fama-French approach: capitalization (Small and Big) and book-tomarket ratio (Low, Middle and High). The standard CAPM and three-factor regression equations are estimated. The typical Fama and French results are not obtained. At best, the results are mixed. They show that Nepalese capital market provides excess return for big value-stocks and lower excess return for small growth-stocks. It is possible that this result is attributable to the biases in the listed corporate sector. Financial sector companies dominate the listing on the Nepal Stock Exchange. Because of the impossibility of elimination financial companies from the sample, it is impossible to be categorical about this attribution. We recommend that the study be replicated after a few years when either more companies become available or longer time series of data becomes available.
\end{abstract}

\section{Keywords}

Nepal Stock Exchange, Cross-Sectional Asset Pricing, CAPM, Fama-French Three-Factor Model

\section{Introduction}

The Fama and French (FF) three-factor model has emerged as an alternative explanation for the ongoing debate

"We appreciate the helpful comments of the participants at the Global Finance Conference, 2013. 
on asset pricing. It was developed by Fama and French [1] as a result of increasing empirical evidence that the Capital Asset Pricing Model (CAPM) performed poorly in explaining realized returns [2]. The CAPM, one of the fundamental tenets in financial asset-pricing theory, was developed by Treynor [3] [4], Sharpe [5], Mossin [6] and Lintner [7]. Merton [8] [9], Black [10] and Williams [11] extended it in new directions, such as inter-temporal continuous-time cases, restricted borrowing and heterogeneous beliefs, respectively. It is a single-factor model which considers the beta of the asset as the only important factor to explain the required rate of return for a capital asset. The three-factor model includes two additional risk factors—size and book-to-market (B/M) - that the published literature has found to be significantly correlated with returns. Empirical tests of the three-factor model confirm significantly greater explanatory power than the one-factor CAPM (see survey of literature by Fama and French [12] on stock returns and by McLean and Pontiff [13] on anomalies).

However, most of the research concentrated on the U.S. and developed capital markets may not be applicable to less-developed and emerging capital markets. To the best of our knowledge, no study has been carried out in the context of Nepalese stock market and very few of South Asian markets. The current study attempts to fill the gap by using data from Nepal Stock Exchange (NEPSE). This paper empirically examines the Fama-French three-factor model for the Nepalese stock market. We test the one-factor pricing relationship implied by the CAPM and the three-factor linear pricing model of Fama and French. We analyze whether the market, size and value factors provide enough explanatory power for the cross-section of stock returns.

The remainder of the present study proceeds as follows. Section 2 outlines the Fama-French three-factor model and some related anomalies research. Section 3 details the empirical method employed and describes the various sources of data. Section 4 presents and discusses test results and section 5 offers a summary and conclusion.

\section{Literature Review}

The capital asset pricing model (CAPM) remains perhaps the popular choice among practitioners when it comes to calculating both expected return on stocks and benchmark expected return. The attraction of the CAPM is that it offers powerful yet simple predictions about risk and the relation between expected return and risk. The model's expected return is the sum of the return on the risk-free asset plus an expected premium for risk, where the risk premium is a function of the asset's covariance (beta) with the market. Despite the simplicity, it performs poorly in explaining realized returns. That is, if by creating portfolios at a given point in time with a range of betas, it is not clear that a perfect or near-perfect linear positive relationship between portfolio beta and realized returns actually exists. The beta calculated using a broad-based market index on average explains about 70 percent of the volatility of stock returns.

Similarly, there is now a substantial published literature that documents a return premium to small companies [14] [15] and to high book-value-to-market-value companies (Rosenberg, Reid and Lanstein [16]; Lakonishok, Shleifer and Vishny [17]) that is not captured by beta. Size-related January effect is documented empirically by Keim [18], Reinganum [19], and Roll [20]. Fama and French [21] support the size effect by sorting stock by both size and beta. Their research shows that high-beta stocks have no higher returns than low-beta stocks of the same size.

Other researchers found value effect that returns are predicted by ratios of market value to accounting measures such as earnings, book-value of equity (Basu [22]; Rosenberg, Reid and Lanstein [16]; Fama and French [21]). Similarly, Jegadeesh and Titman [23] find momentum effect that stocks with high returns over the previous three years to twelve months tend to outperform in the future.

To explain these anomalies, Fama and French [1] introduce a three-factor model in which the factors include the return on a broad stock-market index, the excess return on a portfolio of small stocks over a portfolio of large stocks, and the excess return on a portfolio of high book-to-market-value stocks over a portfolio of low book-to-market-value stocks. Fama and French interpret their three-factor model as evidence for a "distress premium”; small stocks with high book-to-market ratios are companies that have performed poorly and are vulnerable to financial distress.

While there have been a few attempts to explain the size effect from a behavioral perspective, behavioral finance has played a central role in explanations for the book-to-market effect. The most common behavioral finance explanation is that the market overreacts to both good and bad company performance. Good performance is rewarded too handsomely by the market and prices are driven above the intrinsic value of the underly- 
ing stock. Bad performance is punished too harshly by the market and prices are driven below the intrinsic value of the stock [17].

Fama and French [24] again explore the relationship between additional risk factors and profitability mainly to explain the behavioral phenomenon. They find that high book-to-market firms tend to be persistently distressed and low book-to-market firms are associated with sustained profitability; and small stocks tend to be less profitable than large stocks. Daniel and Titman [25] investigate whether portfolios that share similar characteristics (size, book-to-market) but load differently on the Fama and French risk factors have different returns as Fama and French predict they would. They conclude that the covariances between a set of high book-to-market stocks and another set of high book-to-market stocks are the result of those firms sharing similar properties rather than sharing a common risk factor.

The study by Daniel, Titman and Wei [26] highlights the need to examine the external validity of the accumulating and controversial U.S.-based research. Several key features of the Fama and French [1] U.S. results are missing or considerably weaker in the Halliwell, Heaney and Sawicki [27] study of Australian market. In particular, the common risk factor underlying book-to-market is noticeably absent for Australia. Also, the overall explanatory power of the three-factor model is significantly lower using Australian data. Faff [28] uses off-theshelf index data to examine the power of the Fama-French three-factor model in the Australian setting. He finds strong support for the three-factor model, but this is tempered by the perverse finding of a significant negative, rather than the expected positive, premium to small-size stocks. Faff notes that this result appears to be consistent with other recent evidence of a reversal of the size effect.

The size and book-to-market effects observed by Fama and French in the US market have been observed also in markets outside of the US (Fama and French [1], Capaul, Rowley and Sharpe [29], Sinquefield [30]). The Fama and French [31] study is undertaken in response to the sparseness of non-U.S. research and provides valuable out-of-sample evidence. They find across twelve of thirteen different markets, over a period from 1975 to 1995, a premium of 7.68 per cent p.a. to value (high book-to-market) stocks. Australia exhibits the greatest premium of the 13 countries at 12.32 per cent. Eleven of the 13 countries produce positive book-to-market coefficients and seven of them produce these with $t$-statistics greater than 2.0.

While the Fama and French [31] study provides rare out-of-sample evidence from thirteen non-U.S. markets, the sample used has severe limitations. The sample is drawn from the Morgan Stanley Capital International (MSCI) data set which is dominated by a relatively small number of large capitalization stocks. In addition, the MSCI data are ambiguous about dividend yields. Consequently, Fama and French [31] can test a two-factor model (three-factor model minus the size factor) and forego any insights from the wider spread of book-tomarket generally evident amongst stocks in the small- to mid-cap range. Fama and French turn the model "global" to present evidence that a two-factor model with a world market and world book-to-market factors explains international stock returns better than the world CAPM.

A study of Fama and French three-factor model for the stock exchange of Thailand by Homsud, Wasunsakul, Phuangnark and Joongpong [32] finds that adding two factors, namely, the size and the book-to-market ratio, to the capital asset pricing model improves the efficiency of the explanation and better captures the tradeoff between risk and return. The same study also finds that the three-factor model can explain risk in stock returns better than the traditional one-factor model.

A similarly study of the stock returns of Athens Stock Exchange by Theriou, Aggelidis, Maditinos and Šević [33] finds no positive relation between risk, measured by beta, and average returns. The same study, however, finds a "size effect" in the cross-sectional variation in average stock returns.

Connor and Sehgal [34] empirically examine the three-factor model of stock returns for India. They find that cross-sectional mean returns are explained by market, size and book-to-market factors.

Griffin [35] presents a comprehensive scrutiny of the time-series variation in stock returns: whether country-specific or global versions of three factors provide better explanation. He finds that domestic factor models explain much more time-series variation in returns and generally have lower pricing errors than the world factor model.

As the preceding review illustrates, most of the research carried out in the developed capital markets and the extant published developed literature on the validity of the Fama and French multifactor asset pricing model is inconsistent with some of the key U.S. results. The current paper aims to improve our knowledge of the applicability of the Fama and French three-factor model in the Nepalese capital market and to contribute to the necessary accumulation of non-U.S. research. 


\section{Empirical Method and Data}

\subsection{Empirical Method}

For the purposes of this study, we need monthly return of each stock, weighted average monthly rate of risk-free return, monthly market return, market capitalization and book-value of each stock included in the sample. The total population of stocks is all the listed companies at the Nepal Stock Exchange (NEPSE) at the end of FY 2009-2010 which is 176 . Monthly return is calculated by using the month-end price of each stock and retrieved from the monthly report of NEPSE from December 2004 to July 2011. So, from the 80 monthly reported data, 79 months' returns are calculated. The NEPSE index is used to calculate market return for the same period. We use the standard measures for return and three factors. The equation to calculate return for individual stocks is

$$
R_{t}=\operatorname{Ln}\left(\frac{P_{t}}{P_{t-1}}\right)
$$

where $R_{t}$ refers to return for month $t, P_{t}$ is the month-end price of the stock, $P_{t-1}$ is the month-end price of the previous month and $L n$ refers to natural logarithm. The same formula is used to calculate monthly market return by using month-end NEPSE Index values. Empirically, logarithmic returns are more likely to be normally distributed and analytically more tractable when linking returns over long intervals (Strong, 1992).

The accounting data from the balance sheet and profit and loss account of each company in the sample are used for book-equity. As fiscal year ends at mid-July each year in Nepal, we use the data up to July of FY 2010-2011. The monthly risk-free rate of return is retrieved from the rate of 91-days treasury bills which are published in monthly National Debt Bulletin of Nepal Rastra Bank, the central bank of Nepal.

From a universe of 176 companies, only 134 companies remain in the sample. A few companies are deleted because relevant accounting data are not available whereas some others were not included because relevant trading data are not available. The companies with negative book value are also not included. A noted departure occurs in the sample: We include both financial and non-financial companies for analysis. Contrastingly, Fama and French [21] include only non-financial companies in their samples. This departure is unavoidable because the NEPSE is hugely concentrated in financial institution as about $80 \%$ of the listed companies are classified as financial institutions and more than $75 \%$ of the trading volume comes from these companies during the fiscal year 2010-2011 (NEPSE, 2011).

The classification of 134 companies in six portfolios is indicated in Table 1 . We first rank all companies by market capitalization (size) at the end of December each year with the smallest 50 percent and largest 50 percent of stocks assigned to two different groups, namely, S and B, for Small and Big, respectively. Independent of the size sort, companies are then ranked by book-to-market ratio at the end of December each year with the smallest 30 percent, the middle 40 percent and the largest 30 percent assigned to three different groups, namely, $\mathrm{L}, \mathrm{M}, \mathrm{H}$, for Low, Middle and High, respectively. The intersection of the two size-groups and three book-to-market groups produces six groups of stocks which are used to compute the Small minus Big (SMB) and High minus Low (HML) returns.

The variable SMB (Small minus Big) represents the risk factor for size. SMB will be different for each month for the average returns of small group (SL, SM and SH) and the average returns of large group (BL, BM and $\mathrm{BH})$.

$$
\begin{aligned}
\mathrm{SMB} & \equiv \text { Small }- \text { Big } \\
& =\text { Average return of Small }- \text { Average return of Big } \\
& =\frac{1}{3}(\mathrm{SH}+\mathrm{SM}+\mathrm{SL})-\frac{1}{3}(\mathrm{BH}+\mathrm{BM}+\mathrm{BL}) .
\end{aligned}
$$

The variable HML (High minus Low) represents the risk factor for equity value. HML will be different for each month for the average returns of high group (SH and $\mathrm{BH}$ ) and the average returns of low group (SL and $\mathrm{BL}$ ).

$$
\begin{aligned}
\mathrm{HML} & \equiv \text { High }- \text { Low } \\
& =\text { Average return of High }- \text { Average return of Low } \\
& =\frac{1}{2}(\mathrm{SH}+\mathrm{BH})-\frac{1}{2}(\mathrm{SL}+\mathrm{BL}) .
\end{aligned}
$$




\subsection{Data}

The sample of 134 companies is categorized by market capitalization and book-to-market value ratios. Small companies (indicated as S) are those which have market capitalization value less than the median market capitalization value of all companies and big companies (indicated as B) are those which have market capitalization value greater than the median value of all companies. Low book-to-market companies (indicated as L) are called growth companies and have book-to-market value ratio in the bottom 30 percent. The middle book-to-market companies (indicated as $\mathrm{M}$ ) are called "neutral” companies and have book-to-market value ratio in the middle 40 percent. High book-to-market companies (indicated as $\mathrm{H}$ ) are called value companies and have book-tomarket value ratio in the top 30 percent. Thus, the intersection of the two sizes and three book-to-market groups produces six portfolios of stocks. The number of companies for each portfolio is presented in Table 1.

The summary statistics shown in Table 2 consists of mean, median and standard deviation of the monthly return of these six portfolios. It shows that portfolio with small capitalization and low book-to-market value ratio is yielding higher monthly average return with lowest variability in return measured as standard deviation. Similarly the portfolio with higher book-to-market value ratio and greater market capitalization has the highest standard deviation with one of the smallest average monthly return. Only one portfolio, SH, has negative average monthly return.

SMB is constructed to measure the additional return investors have historically received by investing in stocks of companies with relatively small market capitalization. This additional return is often referred to as the "size premium”. A positive SMB in a month indicates that small-cap stocks outperformed large-cap stocks in that month. A negative SMB in a given month indicates the large-cap stocks outperformed small-cap stocks. As a point of reference, the historical annualized average premium from January 2005 to July 2011 of the monthly SMB factor is $0.16 \%$ as shown in Table 3. It means that on an average, there is positive size premium in the sampled 134 companies listed at NEPSE.

HML is constructed to measure the "value premium" provided to investors for investing in companies with high book-to-market values (essentially, the value placed on the company by accountants as a ratio relative to

Table 1. Number of companies in portfolios.

\begin{tabular}{crrrrrr} 
& Low (L) & & Mid (M) & High (H) & \multicolumn{2}{c}{ Total } \\
\hline Small (S) & 8 & 37 & 23 & 68 \\
Big (B) & 22 & 37 & 7 & 66 \\
Total & 30 & 74 & 30 & 134 \\
\hline
\end{tabular}

The total population of listed companies on the Nepal Stock Exchange (NEPSE) at the end of 2009-2010 is 176. Removing the companies without relevant accounting data or trading data left a sample of 134 companies. Note that this sample includes both financial and non-financial companies, because financial companies dominate the listing on the exchange. The companies are first ranked by market capitalization (size) and assigned to two different groups, Small and Big. Then, with each group, companies are ranked by book-to-market ratio and assigned to three groups, viz., lowest 30 percent $(\mathrm{L})$, middle 40 percent $(\mathrm{M})$ and highest 30 percent $(\mathrm{H})$. These groups are then used to calculate the returns for Small minus Big (SMB) and High minus Low (HML).

Table 2. Summary statistics.

\begin{tabular}{cccc}
\hline Portfolio & Average Return & Median & Standard Deviation \\
\hline SL & $0.724 \%$ & $0.334 \%$ & $3.415 \%$ \\
SM & $0.218 \%$ & $0.250 \%$ & $4.642 \%$ \\
SH & $-0.070 \%$ & $-0.119 \%$ & $4.571 \%$ \\
BL & $0.652 \%$ & $0.871 \%$ & $5.313 \%$ \\
BM & $0.167 \%$ & $0.211 \%$ & $6.373 \%$ \\
BH & $0.013 \%$ & $-0.548 \%$ & $7.216 \%$ \\
Market & $0.493 \%$ & $0.782 \%$ & $8.383 \%$ \\
Risk-Free & $0.381 \%$ & $0.322 \%$ & $0.183 \%$ \\
\hline
\end{tabular}

The table gives the distributional properties of returns of the six portfolios, designated by capitalization and book-to-market ratio. $\mathrm{S}=\mathrm{Small}$ capitalization, $\mathrm{B}=$ Big capitalization. $\mathrm{L}$ = Low book-to-market ratio, $\mathrm{M}$ = Middle book-to-market ratio, $\mathrm{H}$ = High book-to-market ratio. For comparison, similar distributional properties are provided for the market index and risk-free rate. The data reflect the sample period from December 2004 to July 2011. From monthly returns of 80 months, 79 returns are calculated. 
the value the public markets placed on the company, commonly expressed as B/M). A positive HML in a month indicates that value stocks outperformed growth stocks in that month. A negative HML in a given month indicates the growth stocks outperformed value stocks in that month. Over the time period from January 2005 to July 2011 annualized average of the monthly such premium for value stocks is $-8.60 \%$. It shows that on average, growth stocks (low book-to-market ratio) are providing higher premium in Nepalese capital market.

\subsection{Correlation among the Portfolio Returns}

The correlation matrix of the calculated portfolios shows that monthly risk-free rate of returns has negative correlation with other variables. All the portfolios' monthly returns as well as monthly market returns are positively correlated. Moreover, almost all correlation coefficient are significant at 5 percent level. The relationship of SL with $\mathrm{BL}, \mathrm{BM}$ and $R_{m}$ is not significant. Similarly, the correlation coefficient between $R_{f}$ and $R_{m}$ is also not significant at 5 percent level. The highest positive correlation is between SH and BM with coefficient 0.725 and the highest negative correlation is between $\mathrm{SH}$ and RF with coefficient -0.535 (Table 4).

\section{Results}

Following the tradition, we provide two sets of results. Because the three-factor model is an extension of the standard CAPM, CAPM serves as a nice benchmark.

\subsection{CAPM (Single-Factor Model)}

The regression model for CAPM is as follows:

$$
R_{p t}-R_{f t}=\alpha_{p}+\beta_{p}\left(R_{m t}-R_{f t}\right)+\varepsilon_{p t},
$$

where the notation is standard. For each of the six portfolios, 79 excess monthly returns are regressed on excess market returns. Contrary to the previous studies, the results for our sample show that market risk tends to be higher for big companies in comparison with small companies. But this result is consistent with Halliwell, Heaney and Sawicki [27], who find that small companies have lower betas. Table 5 shows that betas for all the portfolios are less than one and only one beta (portfolio SL) is not significant.

Table 3. Average annualized premium.

\begin{tabular}{ccc}
$R_{m}-R_{f}$ & HML & SMB \\
\hline $1.35 \%$ & $-8.60 \%$ & $0.16 \%$ \\
\hline
\end{tabular}

This table provides a measure of the incremental return received on stocks of companies in the category of High-minus-Low book-to-value ratio and Small-minus-Big capitalization. For comparison, the incremental return on the market index is provided. The data reflect the sample period from December 2004 to July 2011. From monthly returns of 80 months, 79 returns are calculated.

Table 4. Correlation matrix.

\begin{tabular}{|c|c|c|c|c|c|c|c|c|}
\hline & SL & SM & $\mathrm{SH}$ & $\mathrm{BL}$ & $\mathrm{BM}$ & $\mathrm{BH}$ & $R_{f}$ & $R_{m}$ \\
\hline SL & 1 & & & & & & & \\
\hline SM & 0.272 & 1 & & & & & & \\
\hline $\mathrm{SH}$ & 0.299 & 0.669 & 1 & & & & & \\
\hline BL & $0.060^{*}$ & 0.634 & 0.583 & 1 & & & & \\
\hline $\mathrm{BM}$ & 0.236 & 0.601 & 0.725 & 0.802 & 1 & & & \\
\hline $\mathrm{BH}$ & 0.294 & 0.634 & 0.538 & 0.562 & 0.597 & 1 & & \\
\hline$R_{f}$ & $-0.009^{*}$ & -0.407 & -0.535 & -0.329 & -0.411 & -0.327 & 1 & \\
\hline$R_{m}$ & $0.002^{*}$ & 0.403 & 0.270 & 0.680 & 0.566 & 0.510 & $-0.169^{*}$ & 1 \\
\hline
\end{tabular}

The table provides correlations among the monthly returns of the six portfolios described in Table 1 . The portfolios are designated by capitalization and book-to-market ratio. $\mathrm{S}=$ Small capitalization, $\mathrm{B}=$ Big capitalization. $\mathrm{L}=$ Low book-to-market ratio, $\mathrm{M}=\mathrm{Middle}$ book-to-market ratio, $\mathrm{H}=\mathrm{High}$ book-to-market ratio. The data reflect the sample period from December 2004 to July 2011. From monthly returns of 80 months, 79 returns are calculated. For comparison, correlations are provided for the market index and risk-free rate. The bolded numbers (with an asterisk) show the correlation that is significant at 5 percent level. 
Table 5. CAPM regressions.

\begin{tabular}{ccccc}
\hline Portfolio & $\alpha$ & $\beta$ & $R^{2}$ & $p$-value \\
\hline SL & 0.003 & 0.003 & 0.000 & 0.924 \\
SM & -0.002 & 0.232 & 0.364 & 0.000 \\
SH & -0.005 & 0.159 & 0.200 & 0.000 \\
BL & 0.002 & 0.435 & 0.708 & 0.000 \\
BM & -0.003 & 0.440 & 0.576 & 0.000 \\
BH & -0.004 & 0.448 & 0.505 & 0.000 \\
\hline
\end{tabular}

The table provides the results of the regression of the standard CAPM equation given by $R_{p t}-R_{f t}=\alpha_{p}+\beta_{p}\left(R_{m t}-R_{f t}\right)+\varepsilon_{p t}$. The portfolios are designated by capitalization and book-to-market ratio. $\mathrm{S}=$ Small capitalization, $\mathrm{B}=$ Big capitalization. $\mathrm{L}=\mathrm{Low}$ book-to-market ratio, $\mathrm{M}=\mathrm{Middle}$ book-to-market ratio, $\mathrm{H}=$ High book-to-market ratio. The data reflect the sample period from December 2004 to July 2011 . From monthly returns of 80 months, 79 returns are calculated. Only one portfolio (SL) shows insignificant result.

\subsection{Three-Factor Model}

Fama and French hypothesize that the return of big-size portfolio is less than small-size portfolio, implying that small minus big (SMB) coefficient should be positive. However, our sample shows that out of 79 months the big-size portfolio return is higher than the small-size return for 41 months. Further, 47 months' portfolio returns on high-minus-low book-to-market portfolio are negative whereas the remaining 32 months' returns are positive.

The regression model for the three-factor model is as follows:

$$
R_{p t}-R_{f t}=\alpha_{p}+\beta_{p}\left(R_{m t}-R_{f t}\right)+s_{p} S M B_{t}+h_{p} H M L_{t}+\varepsilon_{p t},
$$

where the notation is standard.

Table 6 describes the estimates from the regression model for each of the six portfolios. The first portfolio, SL, has a $p$-value of 0.167 ; it is not significant at 5 percent level. The regression equations for remaining five portfolios are found to be significant at 1 percent level. The highest $R^{2}$ is for BH portfolio at 0.788 . Similarly, most of the coefficients in the regression model for these five portfolios are significant.

The alpha term is the intercept and it shows the excess return the portfolio earned. In other words, if the alpha is positive, the asset earned a return greater than it should have given its level of risk; if the alpha is negative, the asset earned a return lower than it should have given its level of risk. Here the estimates of alpha values for all portfolios are positive but none of them is significant.

The size- and value-factors as surrogates for non-market-specific risk should have positive returns. Therefore, value stocks should have higher returns than growth stocks; small stocks should have higher returns than large stocks; and small value stocks should have the highest returns of all.

The regression results presented in Table 6 show that coefficients of market premium (beta) are positive for all portfolios and they are significant at 95 percent level for portfolios SM, SH, BL and BH. It can be inferred from these results that one of the three factors, market risk premium, is the prime component of required return for stocks. This result is also consistent with the CAPM result discussed earlier.

In case of premium for value stocks, the regression results show that there is a significant positive relationship between SM, SH, BM and BH portfolio returns with HML factor. In addition, these estimates are significant. This means that HML factor possess some explanatory power for providing excess return to small value stocks. The portfolios of BH and SH have highest coefficients of HML (1.222 and 0.728) implying that value stocks are providing higher return in Nepalese capital market. This result supports one of the findings of Fama and French as well as other studies (e.g., Malin and Veeraraghavan [36] and Homsud, Wasunsakul, Phuangnark and Joongpong [32]) which show that the value stocks would yield more excess return than growth stocks. The CAPM calculation for the same portfolios also shows that big stocks are providing higher return than small stocks in Nepalese market. However the coefficients of SMB are significant only for BL, BM and BH portfolios but the coefficients are negative. This finding shows that big stocks are providing more excess return than small stocks in Nepalese market. This result is not consistent with Fama and French findings because they find that small stocks outperform big stocks. The regression results show that Nepalese market is providing excess return for big value stocks and lower excess return for small growth stocks. On average, the explanation of Fama and French [1] 
Table 6. Regression analysis of three-factor model.

\begin{tabular}{|c|c|c|c|c|c|c|c|c|c|c|}
\hline \multirow{2}{*}{ Portfolio } & \multicolumn{4}{|c|}{ Coefficients } & \multicolumn{4}{|c|}{$p$-value of Coefficients } & \multicolumn{2}{|c|}{ Model } \\
\hline & $\alpha$ & $\beta$ & $h$ & $s$ & $p_{\alpha}$ & $p_{\beta}$ & $p_{h}$ & $p_{s}$ & $R^{2}$ & $p$-value \\
\hline SL & 0.0037 & 0.1008 & 0.0630 & 0.3263 & 0.340 & 0.109 & 0.567 & 0.026 & 0.065 & 0.167 \\
\hline SM & 0.0020 & 0.2562 & 0.5553 & 0.2272 & 0.653 & 0.001 & 0.000 & 0.177 & 0.337 & 0.000 \\
\hline $\mathrm{SH}$ & 0.0005 & 0.1424 & 0.7280 & 0.1438 & 0.902 & 0.043 & 0.000 & 0.370 & 0.382 & 0.000 \\
\hline $\mathrm{BL}$ & 0.0018 & 0.1968 & -0.1134 & -0.8036 & 0.642 & 0.002 & 0.301 & 0.000 & 0.628 & 0.000 \\
\hline $\mathrm{BM}$ & -0.0005 & 0.1472 & 0.2379 & -0.8781 & 0.927 & 0.084 & 0.112 & 0.000 & 0.521 & 0.000 \\
\hline $\mathrm{BH}$ & 0.0050 & 0.1553 & 1.2217 & -0.6210 & 0.208 & 0.016 & 0.000 & 0.000 & 0.788 & 0.000 \\
\hline
\end{tabular}

The table provides the results of the regression of the standard CAPM equation given by $R_{p t}-R_{f t}=\alpha_{p}+\beta_{p}\left(R_{m t}-R_{f t}\right)+s_{p} S M B_{t}+h_{p} H M L_{t}+\varepsilon_{p t}$. The portfolios are designated by capitalization and book-to-market ratio. $\mathrm{S}=$ Small capitalization, $\mathrm{B}=$ Big capitalization. $\mathrm{L}=\mathrm{Low}$ book-to-market ratio, M = Middle book-to-market ratio, H = High book-to-market ratio. The data reflect the sample period from December 2004 to July 2011 . From monthly returns of 80 months, 79 returns are calculated. Only one portfolio (SL) shows insignificant result.

that small capitalized and high book-to-market-value stocks generate high returns as compensation for higher systematic risk is partially true in Nepalese capital market.

\section{Conclusion and Final Remarks}

We study the efficacy of the Fama-French three-factor model to explain realized returns in the Nepalese capital market, represented by the Nepal Stock Exchange. Both the traditional CAPM and the three-factor models are estimated on a sample of Nepalese companies. The results are mixed. The results show that Nepalese capital market provides excess return for big value-stocks and lower excess return for small growth-stocks. The typical Fama and French results are not obtained. It is possible that this result is attributable to the listed corporate sector. Financial sector companies dominate on the Nepal Stock Exchange. It is impossible to eliminate financial companies from the sample.

Given the above, it would be useful to replicate the study after a few years when either more companies become available or longer time series of data becomes available.

\section{References}

[1] Fama, E.F. and French, K.R. (1993) Common Risk Factors in the Returns on Stocks and Bonds. Journal of Financial Economics, 33, 3-56. http://dx.doi.org/10.1016/0304-405X(93)90023-5

[2] Gaunt, C. (2004) Size and Book to Market Effects and the Fama-French Three-Factor Asset Pricing Model: Evidence from the Australian Stock Market. Accounting \& Finance, 44, 27-44. http://dx.doi.org/10.1111/j.1467-629x.2004.00100.x

[3] Treynor, J.L. (1961) Market Value, Time and Risk (Unpublished Manuscript).

[4] Treynor, J.L. (1962) Toward a Theory of Market Value of Risk Assets (Unpublished Manuscript, a Revised Version Was Published in Korajczyk, Robert, A, Ed., 1999, Asset Pricing and Portfolio Performance: Models, Strategy and Performance Metrics, Risk Books, London, 15-22).

[5] Sharpe, W.F. (1964) Capital Asset Prices: A Theory of Market Equilibrium under Conditions of Risk. Journal of Finance, 19, 425-442. http://dx.doi.org/10.1111/j.1540-6261.1964.tb02865.x

[6] Mossin, J. (1966) Equilibrium in a Capital Asset Market. Econometrica, 34, 768-783. http://dx.doi.org/10.2307/1910098

[7] Lintner, J. (1965) The Valuation of Risk Assets and the Selection of Risky Investments in Stock Portfolios and Capital Budgets. Review of Economics and Statistics, 47, 13-37. http://dx.doi.org/10.2307/1924119

[8] Merton, R.C. (1969) Lifetime Portfolio Selection under Uncertainty: The Continuous-Time Case. Review of Economics and Statistics, 51, 247-257. http://dx.doi.org/10.2307/1926560

[9] Merton, R.C. (1973) An Intertemporal Capital Asset Pricing Model. Econometrica, 41, 867-887. http://dx.doi.org/10.2307/1913811

[10] Black, F.S. (1972) Capital Market Equilibrium with Restricted Borrowing. Journal of Business, 45, 444-454. http://dx.doi.org/10.1086/295472

[11] Williams, J.T. (1977) Capital Asset Prices with Heterogeneous Beliefs. Journal of Financial Economics, 5, $219-239$. 
http://dx.doi.org/10.1016/0304-405X(77)90019-8

[12] Fama, E.F. and French, K.R. (2004) The Capital Asset Pricing Model: Theory and Evidence. Journal of Economic Perspectives, 18, 25-46. http://dx.doi.org/10.1257/0895330042162430

[13] McLean, R.D. and Pontiff, J. (2016) Does Academic Research Destroy Stock Return Predictability? Journal of Finance, 71, 5-32. http://dx.doi.org/10.1111/jofi.12365

[14] Banz, R.W. (1981) The Relationship between Return and Market Value of Common Stocks. Journal of Financial Economics, 9, 3-18. http://dx.doi.org/10.1016/0304-405X(81)90018-0

[15] Reinganum, M.R. (1981) A New Empirical Perspective on the CAPM. Journal of Financial and Quantitative Analysis, 16, 429-462. http://dx.doi.org/10.2307/2330365

[16] Rosenberg, B., Reid, K. and Lanstein, R. (1985) Persuasive Evidence of Market Inefficiency. Journal of Portfolio Management, 11, 9-17. http://dx.doi.org/10.3905/jpm.1985.409007

[17] Lakonishok, J., Shleifer, A. and Vishny, R.W. (1994) Contrarian Investment, Extrapolation, and Risk. Journal of Finance, 49, 1541-1578. http://dx.doi.org/10.1111/j.1540-6261.1994.tb04772.x

[18] Keim, D.B. (1983) Size-Related Anomalies and Stock Return Seasonality: Further Empirical Evidence. Journal of Financial Economics, 12, 13-32. http://dx.doi.org/10.1016/0304-405X(83)90025-9

[19] Reinganum, M.R. (1983) The Anomalous Stock Market Behavior of Small Firms in January: Empirical Tests for TaxLoss Selling Effects. Journal of Financial Economics, 12, 89-104. http://dx.doi.org/10.1016/0304-405X(83)90029-6

[20] Roll, R. (1983) On Computing Mean Returns and the Small Firm Premium. Journal of Financial Economics, 12, 371386. http://dx.doi.org/10.1016/0304-405X(83)90055-7

[21] Fama, E.F. and French, K.R. (1992) The Cross-Section of Expected Stock Returns. Journal of Finance, 47, 427-465. http://dx.doi.org/10.1111/j.1540-6261.1992.tb04398.x

[22] Basu, S. (1983) The Relationship between Earnings’ Yield, Market Value and Return for NYSE Common Stocks: Further Evidence. Journal of Financial Economics, 12, 129-156. http://dx.doi.org/10.1016/0304-405X(83)90031-4

[23] Jegadeesh, N. and Titman, S. (1993) Returns to Buying Winners and Selling Losers: Implications for Stock Market Efficiency. Journal of Finance, 48, 65-91. http://dx.doi.org/10.1111/j.1540-6261.1993.tb04702.x

[24] Fama, E.F. and French, K.R. (1995) Size and Book to Market Factors in Earnings and Returns. Journal of Finance, 50, 131-155. http://dx.doi.org/10.1111/j.1540-6261.1995.tb05169.x

[25] Daniel, K.D. and Titman, S. (1997) Evidence on the Characteristics of Cross Sectional Variation in Stock Returns. Journal of Finance, 52, 1-33. http://dx.doi.org/10.1111/j.1540-6261.1997.tb03806.x

[26] Daniel, K., Titman, S. and Wei, K.C. (2001) Explaining the Cross-Section of Stock Returns in Japan: Factors or Characteristics. The Journal of Finance, 56, 743-766. http://dx.doi.org/10.1111/0022-1082.00344

[27] Halliwell, J., Heaney, R. and Sawicki, J. (1999) Size and Book to Market Effects in Australian Share Markets: A Time Series Analysis. Accounting Research Journal, 12, 122-137.

[28] Faff, R. (2001) An Examination of the Fama and French Three-Factor Model Using Commercially Available Factors. Australian Journal of Management, 26, 1-17. http://dx.doi.org/10.1177/031289620102600101

[29] Capaul, C., Rowley, I. and Sharpe, W.F. (1993) International Value and Growth Stock Returns. Financial Analysts Journal, 49, 27-36. http://dx.doi.org/10.2469/faj.v49.n1.27

[30] Sinquefield, R.A. (1996) Where Are the Gains from International Diversification? Financial Analysts Journal, 52, 814. http://dx.doi.org/10.2469/faj.v52.n1.1961

[31] Fama, E.F. and French, K.R. (1998) Value versus Growth: The International Evidence. Journal of Finance, 53, 19751999. http://dx.doi.org/10.1111/0022-1082.00080

[32] Homsud, N., Wasunsakul, J., Phuangnark, S. and Joongpong, J. (2009) A Study of Fama and French Three-Factor Model and Capital Asset Pricing Model in the Stock Exchange of Thailand. International Research Journal of Finance and Economics, 25, 31-40.

[33] Theriou, N.G., Aggelidis, V.P., Maditinos, D.I. and Šević, Ž. (2010) Testing the Relation between Beta and Returns in the Athens Stock Exchange. Managerial Finance, 36, 1043-1056. http://dx.doi.org/10.1108/03074351011088441

[34] Connor, G. and Sehgal, S. (2001) Tests of the Fama and French Model in India. Working Paper, London School of Economics, London.

[35] Griffin, J.M. (2002) Are the Fama and French Factors Global or Country Specific? Review of Financial Studies, 15, 783-803. http://dx.doi.org/10.1093/rfs/15.3.783

[36] Malin, M. and Veeraraghavan, M. (2004) On the Robustness of the Fama and French Multifactor Model: Evidence from France, Germany, and the United Kingdom. International Journal of Business and Economics, 3, 155-176. 